\title{
SOCIEDADE DE CONTROLE E ABOLIÇÃO DA PUNIÇÃO
}

\author{
Edson Passetti \\ Professor do Departamento de Política e do Programa de Pós-Graduação em Ciências Sociais e \\ Coordenador do Núcleo de Sociabilidade Libertária da PUC-SP
}

\begin{abstract}
Gosto muito das coisas desimportantes,
como os insetos. Não só das coisas,

mas também dos homens desimportantes, que eu chamo de desheróis.
\end{abstract}

Manoel de Barros

0 abia-se no início do século XX que alguma reviravolta ocorreria desde a efetiva Comuna de Paris, em 1871, e a ampliada intervenção do Estado na sociedade. Anunciava-se, desde então, a pertinência do socialismo de inspiração marxista que viria a dividir o planeta. Imaginou-se, mais tarde, que os efeitos da revolução russa convulsionariam as relações sociais, mas o que ocorreu não ultrapassou o projeto de reforma na propriedade, deixando inalterado o fortalecimento do Estado. As repercussões acomodaram-se em torno de uma esperança de justiça social, contribuindo para a emergência do Estado de Bem-Estar Social. Sob este pano de fundo, que desmoronou conjuntamente no último quartel do século, os conservadores reapareceram engrandecidos, pretendendo o retorno à economia de mercado. Emergia outra versão universalista com base no binômio democracia-liberdade de mercado globalizado. Todavia, a última década atestou a impossibilidade do Estado afastar-se por completo das intervenções e redimensionou a utopia conservadora num liberalismo social que não camufla os setores onde o investimento prioritariamente se realiza sob o regime de uma constante reforma administrativa.

Estamos no interior de um século no qual a sociedade disciplinar cedeu lugar gradativamente à sociedade de controle, cujo alvo deixou de ser a população e passou a ser o planeta: é um tempo de convivência e ultrapassagem da biopolítica da população para a ecopolítica planetária.

O trajeto percorrido neste século deixou inalterado o sentido do castigo e da recompensa como formas de sociabilidade, pretendendo ajustá-los às novas conformações acerca da produção da vida, mas isto não impediu a proliferação de revoltas instabilizadoras da segurança de soberanos nacionais e transnacionais. Dentre estas, marcaram a vida social os novos equacionamentos acerca da punição, que deixaram desvestidas as instituições de reclusão.

Os desmanchos do socialismo e do Estado de BemEstar Social, anunciados pelas revoltas de 1968, ${ }^{1}$ trouxeram à cena política manifestações voltadas para baldar o espetáculo de denúncias, levando o Estado a desdobrarse para afirmar sua soberania, ancorada na política dos direitos humanos ou no multiculturalismo. A sociedade de controle contínuo, imaginando-se mais segura graças à eletrônica e à transformação da guerra tradicional em guerra aérea, gestou no seu interior outras vítimas e resistências avessas à acomodação à suposta centralidade do poder.

Num mundo que se diz novo e em reforma permanente, emergiu o abolicionismo penal como saber voltado para questionar o castigo naturalizado, sua correlata acomodação no direito penal, e dissecar a estupidez do aprisionamento, principalmente de crianças e jovens. O abolicionismo penal atualiza a secular crítica libertária ao sentido das prisões e projeta virtualidades para o futuro, 
independentemente das reações conservadoras. Insere-se como forma de saber que abandona o universalismo para encontrar, no presente, conceitos que se revejam no decorrer do acontecimento.

Distanciado das invocações éticas generalizantes diante do tempo atual de violências e amplitude das misérias disseminadas por este planeta eletrônico que se pretende realizador de uma paz cosmopolita, o abolicionismo penal apresenta-se como uma invenção de micropolítica.

\section{DIVÍDUOS}

Em linhas gerais, a sociedade disciplinar acomoda o sistema de castigos à utilidade dos corpos de maneira normalizadora, com vista a deles obter maiores docilidades. Trata-se de uma sociabilidade orquestrada por sanções que dinamizam a centralidade do poder, educando em função da adaptação. Persuadir e adequar são meios para a pacificação das tensões, o aumento de riqueza e regras de poder pretendendo agir preventivamente com o objetivo de conter a proliferação dos sujeitos perigosos à coesão social.

Nesta sociedade, investe-se num corpo são para o Estado que conjuga, na Europa, diversas práticas médicas. O Estado alemão do século XVIII governa a prática médica centrada na melhoria do nível de vida da população em geral, não se atendo em especial ao corpo dos trabalhadores. A medicina urbana francesa vai noutra direção. Atua na regulação homogênea do mercado por meio de uma razão política que investe na dissipação do medo das fábricas, construções, cemitérios e insalubridades que geram pequenos pânicos diante da ameaça operária. Identifica o pobre como gerador de periculosidades e se fortifica pelo controle político-científico do meio. A cidade limpa e organizada precisa de trabalhadores saudáveis dispostos em espaços disciplinares, garantindo sua maior utilidade. Está em jogo solucionar problemas como o subsolo, deixando intocável a propriedade privada de superfície. A medicina inglesa, por seu turno, investe no esquadrinhamento geral por meio de uma política de saúde que envolve assistência ao pobre e controle da saúde dos operários realizando-se nos health services. ${ }^{2}$

Ao pretender fundir a extração de energias econômicas do corpo a dispositivos redutores de contestação política, a sociedade disciplinar institui e instala as internações para os sujeitos produtivos, os verdadeiramente vivos, da mesma maneira que o faz com os diferentes, os potencialmente perigosos. A história do corpo-espécie sob o minucioso sistema de sanções disciplinares promove um acontecimento que nos desloca para o investimento nos efeitos disciplinares disseminados socialmente e que não recorrem obrigatoriamente à lei. São demarcados tanto lugares para os corpos sãos e perigosos, quanto para a política em partidos, parlamentos e resistências.

O mal deve ser localizado, vigiado e medicalizado como forma de prevenção. A sociedade disciplinar assimila os efeitos do poder soberano como uniformização das diferenças e recoloca a figura central da soberania no previsível combate entre forças protagonistas e antagonistas. Da troca simples e pacífica de governos à revolução restauradora de tiranias em nome da maioria vive-se um circuito alimentado pelo mecanismo polimorfo das disciplinas. Neste circuito, a substituição de soberanos caracteriza-se como uma invariância diante da dinâmica disciplinar, e isto nos leva a entender por que a realização histórica do socialismo autoritário ocorreu como o reverso da moeda.

Estamos num tempo de uma biopolítica da população que estabelece o lugar para governar e resistir, cujos bens maiores são a igualdade política e a liberdade individual. Entretanto, a desigualdade, produto da exploração, reativa resistências em função da dissolução do poder soberano da mesma maneira que no interior dos espaços disciplinares envoltos na rede de poder emergem resistências. Elas atravessam a estratificação social fazendo emergir múltiplos questionamentos que irão da despsiquiatrização proposta por Freud (que ainda recoloca o lugar do soberano) e posteriormente à antipsiquiatria até as proposições jurídicas despenalizadoras (que deixam o castigo intocado) e o atravessar da fronteira promovido pelo abolicionismo penal.

As resistências avessas aos universalismos também são gestadas, provocando possibilidades de contrapoderes que se insurgirão diante das reformas. A ciência, com seu acesso racional à profundidade, pretendeu-se reveladora da consciência da verdade, mas isso deixou de ser suficiente. Redescobriu-se que ela convive com outros saberes e que desta coexistência aparecem outras possibilidades emergenciais para as resistências que já não se acomodam no teatro de denúncias, encenado pelos efeitos de consciência profunda trazidos com exclusividade pelo discurso científico com a indignidade de pretender falar pelos outros.

A sociedade de controle, característica do século XX, não suprime nem substitui a sociedade disciplinar, mas reescalona prioridades soberanas. Os acontecimentos internacionalistas anunciados no século anterior realizam- 
se não só pela globalização capitalista mas também pela socialista, redimensionando os interesses no corpo. Assistimos a ultrapassagem da era do corpo-espécie como alvo dos governos para a do corpo-planeta em que a biopolítica da população transmuta-se em ecopolítica planetária.

Diversas procedências poderiam ser citadas da sociedade de controle, abarcando desde o acontecimento atômico que redireciona os sentidos da segurança, da guerra, do conhecimento, até, e principalmente, a nova dinâmica acerca da utilidade e docilidade dos corpos. Nesta sociedade, não estamos mais frente a um corpo são para o Estado (útil e dócil), pois mantidas as premissas da prevenção e da periculosidade, incluindo as mais diversas manifestações culturais, agora o Estado volta-se para o corpo são (útil e participativo). É dele que o Estado se ocupará e, desta maneira, não será estranho que a grandiosidade da miséria venha a assumir proporções surpreendentes e se investirá numa medicina de seguro privado.

O maquinismo do corpo-espécie assume outras proporções e é revolucionado pela tecnologia eletrônica que exige para si o uso inteligente de partes do corpo. Pouco importa se é um corpo com deficiência ortopédica, pois a exigência dinamiza a adequada extração de fluxos inteligentes de suas partes. A produtividade passa a ser programada como forma de acesso e realização da riqueza. Ao lado das tecnologias políticas e da expansão de processos normalizadores com funções reguladoras, aparecem a programação e a simultaneidade.

Gilles Deleuze (1995) indica que a fábrica cedeu lugar à empresa, a escola à formação permanente e o exame ao controle contínuo. É o tempo dos fluxos inteligentes sendo consumidos, prescindindo-se para tal da esperada docilidade da sociedade disciplinar. Trata-se de uma sociedade que investe no incentivo à participação e que consumiu as reservas de autonomia individual pelo sistema repressivo, ultrapassando o sentido da resistência centralizada norteada pelo humanismo. A utopia do bom soberano no Estado (pelo rodízio no governo) se viu superada pelo sonho do bom Estado soberano (democrático-universalista). Utilidade e participação, nesta sociedade, constituem o binômio que ultrapassa o anterior, formado por utilidade e docilidade, cujas fronteiras internas cederam à organização sob a forma de programas.

O mundo dos especialistas cedeu lugar ao tempo de profissionais polivalentes em formação permanente e sob controle contínuo. O lugar político é incentivado como virtualidade, posto que as energias inteligentes dos sujeitos, sendo extraídas em fluxos de múltiplas procedên- cias, ajustam-se à dissolução gradual da ordem estabelecida com base nos espaços disciplinares. A disciplina, que era um dispositivo de longa duração, infinita e contínua, é substituída pelo controle de curto prazo e rotação rápida. Exige-se o rejuvenecimento constante como arte da participação num espetáculo virtual dos cuidados sobre nós estimuladores de formatações que vão da auto-ajuda às apresentações estetizadas de si. Dissipam-se fronteiras imediatas tendo em vista a formação de uma nova territorialização cosmopolita, que não supera a explosão contínua de guetos, etnias, favelas e banditismos, em constante metamorfose, como no caso do narcotráfico. O planejamento produtivo redireciona-se para a organização por meio de programas de controle, fazendo aparecer modulações que sucedem os moldes como forma de extração das energias.

Não importam mais os indivíduos e tampouco seu corolário, a massa. Os grandes líderes são coisas do passado ou ajustam-se a etnias que pleiteiam tardiamente a condição de Estado nacional sob uma realidade de mercado universal o Estado democrático-universal como utopia da sociedade de controle. No seu interior os sonhos liberais são redimensionados e as massas, agora fragmentadas, são absorvidas pelos fluxos e ajustam-se à telemática, potencializando seu individualismo no interior da mais difundida forma de criação de telerrealidades, a televisão.

Os indivíduos passam na sociedade de controle à condição de divíduos, como ressaltou Deleuze, divisíveis aninhados em bancos de dados, perdendo a sua assinatura em favor do acesso por meio da senha. Não há mais sonho de minoria pretendendo-se maioria soberana. Entramos na sociedade de controle, num mundo da atuação política democrática, em que todos devem participar e no qual a democracia apresenta-se como o valor universal por excelência. O que era uma expectativa liberal no pósII Guerra Mundial consolida-se com o fim do socialismo soviético.

Espera-se que todos participem, e fluxos diversos apresentam-se absorvendo a política em sondagens e rituais eleitorais. Entrechocam-se efetivos de lutas por direitos humanos $^{3}$ ou de garantias a direitos específicos comandados pelo multiculturalismo, com dedicação à cooperação com os menos favorecidos, regidos por organizações não-governamentais norteadas por princípios de civismo. Mais especificamente, por reagrupamentos religiosos propiciando uma religação de indivíduos com grupos, menos por convicções tradicionalistas e mais por sentimento de participação na vida social. Participar é emitir 
opinião, e a televisão é o meio de comunicação de massa que assume a dianteira, difundindo esta forma de integração, sinônimo de democracia, ao mesmo tempo que a redefine pelo avesso.

Seria precipitado entender a religiosidade sob a globalização como efeito da restauração tradicionalista que, em geral, englobaria apenas os localizados fundamentalismos orientais. Também seria pouco proveitoso incensar a televisão como meio principal da transformação religiosa do receptor calcada no ato contínuo da restauração veloz da autoridade tradicional. Muito menos seria concordar com Francis Fukuyama ${ }^{4}$ e identificar a volta aos nichos religiosos como forma explicativa da restauração de valores morais de grupo em face da exacerbação do individualismo grandioso da década de 80 , facilitando a restauração da família.

O processo de participação na sociedade de controle absorve divíduos com a recomendação de evitar-se resistências. O fluxo de participação política sintoniza-se com a programação das partes inteligentes do corpo produtivo, amparados ambos numa difusão generalizada da noção de ética. Como sublinhou Alain Badiou, o prevalecente discurso dos direitos humanos no final do século embalando guerras e confrontando-se com o relativismo cultural desde o final da década de 80 - abraça categorias supostamente universais e anima o conservadorismo em expansão, amortecendo os processos de singularização. Mostra-se "compatível com o egoísmo satisfeito dos opulentos ocidentais, a submissão aos poderosos e à publicidade" (Badiou, 1995:22). Trata-se do tempo do retorno a Kant como capacidade a priori para distinguir o mal, que identifica e faz cessar os sofrimentos e subordina a política à ética, levando o espectador das circunstâncias a um julgamento compassivo e indignado, que olha o mal não como o inverso do bem, mas a partir do que dispõe o bem como supressão do mal. $\mathrm{O}$ discurso universalista dos direitos humanos gera, neste sentido, o acesso ao não-mal, como prevenção geral capaz de suprimir a possibilidade de sua existência como efeito bíblico. É um interceptador da produção de ética das verdades, posto que só existe ética de (política, amor, amizade, ciência...), trazendo a disseminação da forma de afastamento que o autor chama de "niilismo beato": "apenas declarando querer aquilo que o conservadorismo decreta ser impossível e afirmando as verdades contra o desejo do nada é que nos afastamos do niilismo" (Badiou, 1995:51).

Não há ética em geral porque não há o sujeito abstrato. $\mathrm{O}$ niilismo beato externa opiniões, cimento da socia- bilidade, matéria-prima da comunicação, situando-se aquém do verdadeiro e do falso, porque sua função exclusiva é comunicar. E comunicar é aquilo em que se crê desde sempre. ${ }^{5}$ Os fluxos de controle ganham outras complementaridades à televisão e à compaixão cívica das ONGs e grupos religiosos, com o elogio da ética em geral. Entende-se desta maneira por que na sociedade de controle recomenda-se não resistir como fluxo contínuo, reprogramando o sentido da democracia em democracia midiática como expectativa universal.

A ética das verdades rejeita a idéia de extermínio de todo o mal (tema teológico) em benefício da política como singularidade. Traz subjacentes a ela as rebeldias que não podem ser tomadas como expressão de simulacros, traição ou desastre, um forçado inominável, pois seus correlatos são acontecimentos, lealdade e potência do verdadeiro. ${ }^{6}$

Uma derradeira incursão ainda sobre este mundo do bem na sociedade de controle pode ser captada na noção de desprogramação da programação sugerida por Edgar Morin (1993). Para o autor, a era planetária exige a unidade pacífica e fraternal da humanidade geradora de novas diversidades. Propõe que se invista no acontecimento histórico gerador de uma máquina viva capaz de estratégia, na invenção de comportamentos na incerteza e no acaso que respondam à agonia gestada pela tecnociência, máquina artificial que obedece estritamente ao seu programa. Propõe uma finalidade política de hominização para a conservação da humanidade e investe na democracia como reduto para a emergência de idéias heréticas e desviantes, portanto transformadoras. Instaura a noção de estado político como sendo aquele capaz de ultrapassar as inimizades: “...o evangelho da fraternidade está para a ética tal como a complexidade está para o pensamento: apela a que não se direcione ou separe, mas a que se una, e é intrinsecamente re-ligioso, no sentido literal do termo" (Morin, 1993:150). Trata-se de uma religião da incerteza, nosso "porto de salvação", redimensionador do marxismo. Evita-se pensar uma ética do bem que intercepta o mal fazendo aparecer uma ética da fraternidade que realiza, no limite, o último vértice do triângulo erguido pela Revolução Francesa na sociedade disciplinar, completando as experiências desiguais gestadas sob o signo da liberdade e igualdade, com os correlatos socialismos e liberalismos.

A seu modo, Morin remonta outras dimensões da sociedade de controle que se orienta pela ecopolítica em substituição à biopolítica, e ao fazê-lo, recicla o tempo bradando o que supõe sendo a crítica quando nada mais é 
do que a própria realidade da sociedade de controle. Desprogramar a programação fragmentada, para ele, só é possível por meio de outros programas que superem a disjunção entre arte, ciência e espiritualidade. Como sublinhou Foucault, uma nova política da verdade implica a fusão de saberes eruditos e demais saberes, uma instabilidade que agiliza saberes de sujeitos sujeitados ou, no dizer de Deleuze, uma profícua liberdade de rebeldias, ou ainda, o reconhecimento de que precisamos superar as noções de homem, universal e representação. Menos do que conceber o universo particular como universo cósmico e o concreto como universo terrestre, superando as oposições entre o universal e o concreto, o geral e o particular, como pretende Morin, para Deleuze é isto mesmo que a sociedade de controle espera de nós: que tenhamos a convicção de que tudo está em reforma, nada concluído, numa situação de crise das instituições. Que as revoluções se encontram nas linhas de fuga e nos saberes produzidos pela crítica polivalente com base na perícia local e evitando-se generalizações!

Deleuze (1996:47-57) propõe que estabeleçamos a relação entre o atual e o virtual. ${ }^{7} \mathrm{O}$ virtual é entendido como sucessão de imagens fragmentadas e efêmeras que se atualizam na singularidade do acontecimento. No seu interior, o virtual conserva o passado e lhe dá atualidade, fazendo com que o atual apareça como identidade constituída, que por sua vez projeta-se, à revelia, como um virtual que se encontrará noutro espaço. $\mathrm{O}$ atual e o virtual são, portanto, termos indiscerníveis e, conseqüentemente, o inverso da unidade, distinguindo-se por caracteres intrínsecos e não pela posição que ocupam no tempo ou no espaço. São partes de uma continuidade que entrecortam espaços de forma regular ou irregular no tempo, caracterizando os vacúolos, minúsculos vazios onde encontraremos os sentidos para o devir revolucionário, resistências, linhas de fuga.

Devemos agora nos dedicar a um destes pequenos vazios que trafegam nos fluxos, portando devires instabilizadores na sociedade de controle, não conformados às utopias que propõem soluções justas para a sociedade universal e sim para uma miríade de sociedades pautadas na diversidade. Nossa atenção recai sobre o abolicionismo penal, repleto de virtualidades, uma forma de resistir que se conecta com o passado anarquista, ${ }^{8}$ desde William Godwin, com a crítica à naturalização do castigo. $\mathrm{O}$ atual colocado pela vertente abolicionista da pena investe na crítica ao direito penal e ao universalismo da lei, à sociabilidade pautada no castigo e nos efeitos dos redimensionamentos promovidos pelo fluxo reformista penal. Si- naliza, preferencialmente, no Brasil, para a superação da prisão para jovens.

\section{ABOLICIONISTAS}

Abolir a pena é uma forma de conhecer que educa para a abolição do castigo. Elucida a importância da naturalização do castigo numa sociedade incapaz de lidar com forças adversas, de modo que expulsá-las passa a ser o meio de se chegar à purificação do mal. Somos parte de uma sociedade antropoêmica, disse Claude Lévi-Strauss em Tristes trópicos; temos medo de partes da nossa própria criação que nos instabilizam, e assim fundamos inquéritos, que vão da inclusão do princípio do mal na construção de natureza humana até a bondade distorcida pelo estado civil, levando-nos simultaneamente à legitimidade de fronteiras e à conseqüente afirmação de uma autoridade soberana.

A abolição da punição é vista na sociedade disciplinar e de controle como utopia, uma bela utopia a ser compartilhada, e é desta mesma maneira que muitos tratam o fim da penalização, como algo nobre que anuncia o futuro, mas que deve ficar para este mesmo futuro. Alguns dizem que será no interior da utopia igualitária totalizadora que as crianças deixarão de ser propriedade dos pais, que o pátrio-poder se dissolverá em nome da responsabilidade social e que, portanto, poderemos educá-las com vista à realização do talento de cada uma. Outros, como Richard Rorty, têm a esperança de que os cidadãos não façam mal aos necessitados utilizando privadamente os recursos a eles destinados. Espera-se uma solidariedade criativa, uma sensibilidade que não marginalize os diferentes e que encontre um metavocabulário que englobe todos os vocabulários, todas as maneiras de julgar e sentir. Entretanto, não esquecendo que o novo encontra-se no interior de uma ordem, devemos lembrar que muito do que se afirma socialmente independe das supostas determinações ou esforços reformadores. Para nós, que sabemos que os efeitos de dominação são unilaterais e que as relações de poder são reversíveis, importa investir na invenção de uma micropolítica que não subestime a política do Estado. Estamos no campo de uma ética como estética da existência, isenta de qualquer prescrição. Uma boa escolha, então, supõe racionalidade ética, ou seja, sensibilidade política ao intolerável, ao inaceitável, ao inominável. Envolve capacidade de julgamento e diferenciação realizando-se pelas discussões e trocas que sustentam o critério da escolha, uma escolha sempre dirigida pela "razão 
do outro", constituindo o sujeito desta ética e instruindose com os outros e outras artes no sentido oposto ao da constituição do sujeito idêntico. A estética da existência é uma política da arte de viver.

Abolir a injustiça, contemporaneamente, diz respeito ao estudo da formação e educação que constituem a opinião pública e que expressam as formas de conhecimento, percepções e evidências da sociabilidade. Busca-se captar suas transformações múltiplas com a mesma paciência que dedicamos aos estudos específicos sobre a tolerância com a punição e a aplicação de penas legais, num processo contínuo de revisão dos métodos limitadores em nome da boa sociedade. Punir é poder perdoar, e a desculpa institui um circuito tirânico que reforça a centralidade do poder pelo jogo de direitos, que, por sua vez, justifica o universalismo da aplicação da lei e se refaz pelas sanções normalizadoras.

As transformações da opinião são trampolins para notarmos como uma verdade adversa se difunde de modo imperceptível por um certo tempo; é quando reparamos que os primeiros a abraçá-la têm pouco discernimento sobre as extraordinárias conseqüências do entranhamento destes princípios que se ampliam com clarezas e evidências. Ao mesmo tempo, tal estudo exige que se abandone o campo da opinião para se voltar para a instituição de uma discursividade que engloba investigação, instrução e discussão. A ignorância acerca de qualquer assunto, afirmava, em 1793, William Godwin, em Justiça política, deve ser combatida com debates. O sentido de governo é dado pelo uso da força contra o indivíduo que atenta contra a pessoa ou a propriedade de outro, e impõe uma prevenção geral sob a forma de lei universal, designando a justiça criminal ou castigo (dor). Infligir sofrimentos a uma pessoa deriva do ato contínuo que se pauta no direito do pai sobre o filho com base no uso da força, na opinião propagada que associa o mal ao sofrimento e que instaura o combate entre forças, fazendo do castigo uma legítima imposição da dor como forma de supressão do mal. ${ }^{9}$

A legislação positiva converteu a maioria em massa abúlica e covarde, condenada a viver em aborrecida estupidez, posto que a minoria é vista por ela como virtuosa ou depravada. Desta maneira, mesmo quando se estende a penalização para além dos setores mais pobres, os reformistas reiteram suas convicções com base na positividade do castigo. O circuito punitivo se faz e refaz em torno da noção de prevenção, que supõe persuadir as pessoas a não cometerem determinados atos com base na aplicação do castigo. Funda-se, com isso, uma ontologia do crime.
O abolicionismo penal é uma vertente libertária que investe na crítica à punição e que encontrou, no século $\mathrm{XX}$, soluções livres de utopias, presentificando a atuação. Obteve ressonâncias a partir da II Guerra Mundial para acuar o direito penal e questionar os princípios de uma sociabilidade autoritária pautada na centralidade de poder. Pretende discutir a discursividade penalizadora ancorada numa profusão de reformas que atestam e publicizam a inoperância da melhor punição e de seus efeitos disciplinares e de controle, segundo o fluxo contrário ao do "ruim com, pior sem".

O abolicionismo penal, afirma Louk Hulsmann - um dos seus principais formuladores contemporâneos -, é um movimento social e acadêmico. ${ }^{10}$ Procura envolver pessoas e organizações solidárias à liberdade, interrogar os efeitos provocados pelas sucessivas reformas penais modernas, que não solucionam os problemas acumulados no interior do sistema penalizador, e amplificar a constatação acerca da exploração já conhecida e sistematizada desde o século XIX.

O final da II Guerra Mundial anunciou o abolicionismo penal a partir do surgimento da escola de defesa social fundada por Felippo Grammatica, ${ }^{11}$ na Itália, mas veio a ganhar amplitude a partir dos anos 1970, como efeito das revoltas de 1968 - ano apontado com propriedade por Antonio Negri como data fundamental para a compreensão de nossa história e que tem a mesma relevância de 1789 e 1848. Foi o ano das rupturas com as grandes dominações, seus discursos totalizadores e individualistas, que repuseram o anarquismo no debate político, desdizendo seu suposto final localizado na Guerra Civil Espanhola. O investimento titânico de Michel Foucault voltando-se para os micropoderes, o redimensionamento apontado por Gilles Deleuze das singularidades e a aproximação de publicações anarquistas de reconhecimento internacional atestam as várias dimensões que o libertarismo vem assumindo.

O abolicionismo penal é um pensamento que opera no campo da polivalência tática dos discursos. Congrega no seu interior pensadores de perspectivas libertárias como Hulsmann, mas também marxistas do calibre de Nils Christie e Thomas Mathiesen. Afirma o esgotamento das reformas penais levando ao limite as constatações desde Beccaria, no século XVIII, que apontavam para a ineficiência da reclusão, até Foucault, ao desvendar a intrincada conexão entre saberes delinqüenciais e policiais. Dialoga com as vertentes despenalizadoras que privilegiam a diversificação da aplicação de penas como redutores à pri- 
são e não deixa de informar que, subjacente a esta política de direitos humanos, permanece inalterada a criminalização de comportamentos supostamente inaceitáveis. Sabe-se, desde Hegel, que não há penalização que não esteja correlacionada à história e isso nos obriga a concluir em favor dos condenados diante da obtusa, longa e moralista cerimônia de promulgação de sentenças, a corrupção policial e a morosidade administrativa exigindo reformas para melhor funcionar com supostas eficiência e rapidez.

A história do sistema penal é a história das injustiças contra presos, dos erros judiciários, da economia das penas, da transformação da vítima em testemunha, das múltiplas revisões. Nela, quase nunca está em jogo a justiça para a vítima. Não se investe na sua indenização, mas na perpetuação do sistema de vinganças, transformando-a em testemunha, parte do inquérito que alimenta e retroalimenta o sistema punitivo custoso e sempre em expansão.

O sistema penal moderno dirige-se para o controle dos diferentes, produto de uma sociabilidade autoritária capitalista ou socialista, sob a democracia ou fascismo, que não suporta aqueles que pretendem interceptar e que anunciam, segundo Antonin Artaud, verdades que são insuportáveis para a sociedade. São loucos, miseráveis, pobres, prostitutas, homossexuais, crianças e jovens infratores, grupos religiosos, raças, etnias e até populações.

Os luddistas ingleses, em 1812, foram as vítimas preferenciais da framebreaking bill (que estendia a pena de morte aos pobres quebradores de máquinas). As prisões modernas encarceravam sob a inspiração panoptista de Jeremy Benthan, e os loucos eram elevados à condição de doentes mentais nos manicômios. Os hospitais transformavam-se em máquinas de cura, e os socialistas apareciam com voz e veto, instabilizando a ordem filantrópica que desaparecia com o fim dos hospitais gerais no final do século XVIII. No Brasil, o Hospício Pedro II, na metade do século XIX, as penitenciárias e os recolhimentos para menores, que inaugurariam o $\mathrm{XX}$, viriam disciplinar o que passava a ser impossível para a filantropia. Não tardaram a aparecer campos de concentração também para anarquistas, como o de Clevelândia, no Amapá, durante o governo de Arthur Bernardes, no início dos anos 20, muito antes dos campos nazistas, que foram familiares..., dos norte-americanos para japoneses e dos soviéticos para dissidentes, e até dos campos de extermínio japoneses que serviram de espelhos para os nazistas.

A sociabilidade autoritária moderna não suporta o diferente, porta um projeto moralizador com base na concepção de prevenção geral que pretende normalizar a so- ciedade suprimindo ou investindo na esperança de reeducar e integrar os perigosos. Em nome da racionalidade ou da religião, ela estabelece o tráfego intenso entre fé e razão em função de uma moral do rebanho. O século que começou com a realização do sonho do socialismo centralizado como meio para a justiça social encerra-se com a confirmação da democracia como moderna religião de participação; acreditou-se na psicanálise como pacificadora dos desejos e do inconsciente e conviveu-se com o conformismo e as insatisfações étnico-religiosas, centros deflagradores de inconscientes autoritários.

1968 colocou o século em xeque. Desnorteados, muitos desamparados saíram em busca do paradigma perdido, incensando a democracia como valor universal, reiterando a importância da prevenção geral para a segurança e a política, exigindo políticas especiais de repressão e educação, nada mais fazendo que dinamizar novos setores eletrônicos, não excluindo os mecanismos internos à prisão ou de segurança diante de supostos agressores.

A justiça social com redução da pobreza, com maior ou menor intervenção estatal, foi uma forma de dinamização dos setores repressivos, com a privatização de prisões, proliferação de atendimentos filantrópicos preventivos por organizações não-governamentais, e de propagação de uma compaixão cívica aureolada por uma consciência empresarial, despenalizada de parte dos tributos dispensados ao recolhimento público.

$\mathrm{O}$ abolicionismo penal não se furta ao diálogo com o humanismo de final de século, norteado por esta ética da fraternidade. É seu interlocutor privilegiado, questionando os limites das políticas humanistas, pois interessa-lhe saber como reparar as vítimas e compreender os infratores envolvidos em situações-problema tidas como delituosas. A noção de situação-problema ${ }^{12}$ passa a ser fundamental, orientando-nos para o entendimento da relação infrator-vítima, e evitando a reconstrução das técnicas da prova e do inquérito como verdades jurídicas acabadas e a tomada de decisões centralizadoras e punitivas.

O abolicionismo penal está interessado na vítima e no agressor, reduzidos a primeira à condição de testemunha e o segundo de réu pelo sistema penal. Não acredita que o fim das prisões seja uma das utopias da sociedade justa e igualitária e pretende mostrar que é possível suprimi-la a qualquer momento. $\mathrm{O}$ abolicionismo não se pretende utópico e tampouco admite ser tratado como trapaceiro ou irresponsável.

A história das invariantes estatísticas prisionais aponta para uma certa estabilidade, destoando dos registrados 
aumentos de população. As escalas ascendentes e descendentes, quando ocorrem, relacionam-se a efeitos de repressão moral ou político-cultural circunstanciais. Nos últimos tempos, quando se investe em disseminação de direitos, estes efeitos têm aumentado independentemente dos programas de diversificação das penas, refletindo o ajuste entre a reclusão prisional, a reforma eletrônica das prisões e a aparição das chamadas políticas de tolerância zero - respostas conservadoras de segurança que propugnam maior eficiência burocrática por meio do policiamento da sociedade e do Estado. Quer nos fazer crer que chegará o momento em que toda infração será comunicada à autoridade policial, que imediatamente acionará o encaminhamento ao Judiciário, o qual, por sua vez, será capaz de julgar e penalizar o criminoso, em tempo record, pela informatização da polícia, do Judiciário, das ruas, casas, escolas, empresas, conectadas a fluxos de policiamentos de divíduos controlados por bancos de dados. Esta utopia da sociedade de controle desconhece que existe uma sociedade sem penas, não só porque ocorre a incidência da cifra negra (a diferença entre infrações denunciadas na polícia e aquelas efetivamente julgadas pelo direito penal), mas também porque boa parte das infrações é equacionada pelos envolvidos, sem a necessidade das formalidades jurídicas do justo, às vezes de forma pacífica e outras de forma violenta, como as que se dão entre policiais e suspeitos, no interior da economia do narcotráfico ou no intenso percurso de realização do lucro. O que esta utopia não esconde é que a prisão é reconhecida não mais como lugar de ressocialização e futura reintegração, mas como depósito de corpos para os quais os únicos investimentos estão na redução da possibilidade de fuga a zero, sob rigorosa vigilância após o sentenciamento com base no aumento da pena. A sociedade admite que já não sabe o que fazer com os infratores, ao mesmo tempo que imagina a diversificação, a descentralização administrativa e o aumento da penalização como meios de ampliação da prevenção geral. Exige que o indivíduo diferente se conscientize de que será apanhado, e é isto que interessará ao sistema penal. Desaparece a preocupação com o futuro do infrator, e a pena de morte é reescrita com a eternização do confinamento.

As prisões para adultos e jovens agora são inscritas no espetacular e lucrativo ramo da indústria eletrônica, com seus chips e códigos de barra, para vigiar internos e controlar os que vivem em liberdade vigiada ou em semiliberdade, gerando-se com isto uma complexa modernização no conceito de campo de concentração. Nils Christie (1998) mostrou isto, ressaltando que os subúrbios tendem a se transformar nestes novos campos de concentração, habitados na maioria das vezes pelos principais defensores da repressão, os próprios e intolerados diferentes. ${ }^{13}$

A justiça como sinônimo racional de revanche sangrenta deve ser superada. Invertendo-se o saber sobre a prevenção geral - posto que ela se destina, pela ameaça da aplicação do castigo, a uma maioria que não a incorpora - pelo saber sobre a situação-problema, elimina-se a concepção ontológica de crime para se investir no princípio da conciliação. Estão em jogo "respostas-percurso" 14 que envolvem o uso da terapia (observadas as pertinentes anotações de Foucault acerca dos riscos de se substituir a prisão pela terapêutica), a educação (em sentido amplo de sociabilidade, distinto da instrução cujo limite é a laborterapia), a compensação (o que não implica transformar o agressor em escravo da vítima) e a conciliação. O abolicionismo espera que o recrutamento de juízes ocorra também entre os trabalhadores, que estes evitem a arrogância e que prescindam do "pacto sinistro" com os técnicos instrumentalizados por uma competente e neutra avaliação técnica, sobrecarregados de valoração preconceituosa, que faz girar a sentença pela ausência de outra convicção que não seja a internação. No caso de adolescentes infratores, mesmo com a recomendação do ECA para se evitar a internação, não se nota um refluxo no sentenciamento, mas uma certa contribuição para ampliar as exigências por novos presídios (idéia camuflada pela defesa da descentralização ou por propostas que giram em torno de um direito penal para adolescentes). Há nisto uma conservação da mentalidade encarceradora entre juízes, promotores, advogados e técnicos biopsicossociais, e que independe do ECA.

$\mathrm{O}$ abolicionismo penal espera que os intelectuais informem a situação das instituições e associem-se aos encarcerados, pretendendo dar um basta ao lucrativo espetáculo das denúncias. Nele não cabem intelectuais profetas, mas parceiros. Investe-se para que os meios de comunicação de massa dêem atenção às situações-problema e divulguem entre os diferentes sua condição paradoxal de serem ao mesmo tempo os alimentadores do sistema penalizador e suas principais vítimas.

Ettiene de La Boétie, no século XVI, foi o primeiro a desafiar-nos a romper com a servidão voluntária, este ato de consentimento com base na obediência aos mandos e desmandos dos soberanos. Alertava-nos que apenas uma decisão corajosa contra o UM, ignorando-o, por si só, já mostrava as condições para a afirmação da soberania individual. O escrito rebelde do jovem La Boétie ainda po- 
voa os que preferem a sociedade sem soberanos, vivendo-a e não desejando-a como utopia. Sendo então possível uma sociedade sem soberanos, para que serve uma instituição de reclusão para adolescentes, posto que não há mais como negar que a existência da prisão independe do regime político?

No final do século XVIII, William Godwin escreveu o principal libelo antiprisional moderno em seu livro Justiça política, em que identifica as procedências socioeconômicas dos principais habitantes das prisões, assim como o sofisticado circuito de reformas que promove o sistema penal. Para ele, a prisão era inaceitável por explicitar a continuidade entre ricos e pobres, os diferentes, os supostamente perigosos. Não via a prisão como lugar de educativa reflexão crítica do indivíduo diante de um suposto delito juridicamente julgado, lugar de ressocialização ou de futura integração social; mas apenas como um espaço de aprimoramento de delinqüentes e de acelerada corrupção. Deste ponto de vista, a prisão para adolescentes é inaceitável, pois se deve investir na possibilidade de suprimir as punições através da educação e o diálogo, não perdendo de vista que sempre haverá infelicidade e imprevistos, porque inexiste uma bondade absoluta nos homens. Todavia, as exceções apresentam maiores desafios educativos que as justificativas para a existência, ampliação e constante reiteração da prisão ou da lei penalizadora.

Desde La Boétie e Godwin, sabemos da vida de uma sociedade sem soberanos e sem penas que já existe no interior da sociedade autoritária em que vivemos. A prisão não educou, corrigiu ou integrou. No final do século $\mathrm{XX}$, a tolerância com reclusões para adolescentes é mais do que expressão da moral diante do inaceitável; é também o atestado, no Brasil, de que o Estatuto da Criança e do Adolescente, ao pretender garantir a formação do futuro cidadão, não passa de letra morta ao acobertar a política de abandono dos corpos. Resta saber se a sociedade sem soberanos conseguirá desviar a rota de um mundo que se apresenta atualmente com pretensões universalizantes de democracia, direito de segurança. Para tal não deve perder de vista a crítica formulada por anarquistas e marxistas, desde o século XIX, que informa ser a política de direitos uma política de interesses, separação, distinção e confinamentos, e que perpetua o espetáculo da criminalização como gerador de empregos úteis.

$\mathrm{O}$ anarquismo e o abolicionismo são críticas a uma sociedade autoritária pautada pelo exercício da soberania centralizada e hierarquizada. Investem numa sociabi- lidade libertária que suprime verticalizações, propõe a amistosidade das relações com base na diferença, pluralidade e desobediências, posto que, não havendo um absoluto para liberdade, imaginá-la plena é correr riscos de novos totalitarismos. ${ }^{15}$

O abolicionismo penal reconhece a questão econômica como prioritária, mesmo porque não há como negar que os chamados principais delitos consagrados estatisticamente ainda são o roubo e o furto. Evita prejulgar as periferias das metrópoles como centro de armas ilegais, pois é sabido que a indústria bélica é um ramo da produção que investe simultaneamente em legalidades e ilegalidades, em guerras de toda sorte, que atualmente têm no narcotráfico um de seus principais consumidores. Este, por sua vez, recruta seus trabalhadores nas periferias das grandes metrópoles, preferencialmente jovens e desempregados não absorvidos pelas novas regras de utilização produtiva inteligente de partes do corpo da sociedade de controle, que fornecem corpos para a indústria do controle eletrônico prisional. O abolicionismo penal também procura esclarecer que as violências físicas e sexuais contra crianças e adolescentes se propagam no interior de famílias estruturadas ou não, independentemente das procedências de classe (e o critério de Fukuyama para isentar as camadas médias da desestruturação familiar pelo refazer constante de casamentos, apesar do aumento dos divórcios, revela-se um outro boçal conto de fadas). Mostra a importância da crítica radical à prisão e ao direito penal, as circunstanciais conexões com o direito civil para encontrarem-se "respostas-percurso", e identifica no Estatuto da Criança e do Adolescente duas faces da mesma moeda: uma que afirma a pertinência da instituição para os perigosos, o limite defensável pela escola da criminologia crítica, e a outra que exige a aplicação do princípio educativo que, levado a cabo, pacifica esta forma de combate e afirma a pertinência do próprio abolicionismo.

Não se trata de descriminalizar comportamentos com intervenção penal mínima, agindo-se em direção à prisão provisória ou às alternativas à internação, que só fazem aumentar o número de supostos criminosos, beneficiando ainda mais o crescimento burocrático e perpetuando a concepção de prevenção geral-periculosidade. Descriminalizar comportamentos - não esqueçamos - é sempre criminalização de outros, um jeito de reciclar as contínuas reformas. As penas alternativas, como apresentou Christie, nada mais fazem do que fomentar novas prisões e inéditos, porque eletrônicos, campos de concentração. Em nome do humanismo transforma-se a periferia em 
campos de concentração, ajustando-se os interesses políticos e morais aos investimentos da indústria civil, para a construção de mais presídios, e da indústria eletrônica na diversificação das suas áreas de atuação. Democratizar as penalizações pelos princípios das penas alternativas ou por sua extensão a outros comportamentos criminalizáveis, englobando a minoria virtuosa ou depravada, não contém a escalada da criminalidade, não soluciona as violências domésticas, mas faz crescer a burocracia do controle, que, por sua vez, encontra-se mergulhada em infrações regularmente cometidas numa sociedade, seja disciplinar ou de controle, que se baseia numa sociabilidade autoritária. O abolicionismo sabe muito bem que depende como movimento social da difusão e debate nas escolas, nos bairros, nas prisões e principalmente na mídia. ${ }^{16}$

O abolicionismo penal é um estilo de vida e, como disse Hulsman, faz bem à saúde.

\section{NOTAS}

1. "1968 foi o fruto de uma longa série de acontecimentos mundiais e de uma série de correntes de pensamentos internacionais, que já ligavam a emergência de novas formas de lutas à produção de uma nova subjetividade - quando mais não fosse, na crítica ao centralismo e nas reivindicações qualitativas, relativas à 'qualidade de vida'”, Deleuze (1988:123).

2. A esse respeito, ver Foucault, 1978 (capítulos V,VI e XIII) e 1993 (capítulo 6). 3. "É necessário opor-se à divisão de tarefas que freqüentemente nos são propostas: aos indivíduos corresponde indignar-se e falar; aos governos refletir e atuar. É verdade que os bons governos apreciam a santa indignação dos governados, contanto que esta se expresse como algo lírico. É preciso dar-se conta que a miúde são os governantes que falam, os que podem e querem falar com exclusividade. A experiência mostra que se pode, e que se deve, rechaçar o papel teatral da pura e simples indignação que nos propõem. A Anistia Internacional, o Terra dos Homens e o Médicos do Mundo são algumas das iniciativas que criaram este novo direito: o direito dos sujeitos privados de intervir efetivamente na ordem das políticas e das estratégias internacionais. A vontade dos indivíduos deve encarnar-se numa realidade que os governos pretendem monopolizar. Este monopólio é que deve ser pouco a pouco, dia a dia, soterrado." Foucault (1993b:314).

4. Fukuyama (1999:D4 a D8). Para Richard Sennett, em Carne e pedra (1997), a compaixão cívica é um estímulo produzido por nossa carência e não por retidão política ou boa vontade, fruto do desvio dos homens da compreensão religiosa, externando o desespero diante da miséria e identificando a necessidade de agruparmo-nos como forma de reaproximação.

5. A respeito da razão comunicativa como pacificadora, complementar à razão dialética, ver em especial Foucault (1978).

6. Discordando de Badiou, que prefere a fidelidade em lugar da lealdade, sublinhamos a amizade como componente da rebeldia, promotora de insatisfação radical. Ela ocupa o vazio instalado por um acontecimento como devir que escapa ao estado de coisas captadas pelo acontecimento histórico. Comporta o intempestivo nietzscheano e o ato de envelhecer e rejuvenecer no interior do acontecimento, promovendo linhas de fuga ou, mais precisamente, "vacúolos" dentro dos fluxos. Há um sentido para resistir, não como oposição consentida mas como potência do verdadeiro. Todavia, como vacúolo deste mesmo artigo, trafegam várias resistências que vão do sentido Badiou-Deleuze ao de Foucault com a estética da existência. Em comum, ambas invadem os fluxos, inevitavelmente, pela desativação da noção universalista de homem.

7. Para Albert Camus (1996:35), "o pensamento revoltado não pode privar-se da memória: ele é uma tensão perpétua”.

8. A associação entre anarquismo e abolicionismo penal é também sustentada por Delmas-Marty (1992).
9. Jeremy Benthan, em Introdução aos princípios de moral e legislação, afirmava, pelos princípios utilitaristas, que a lei não deve castigar a quem não causa danos; que não se deve aplicar penas maiores que os delitos; e que se deve evitar a lei quando outras medidas forem possíveis. Pena é sinônimo de castigo e as garantias sociais encontram-se na aplicação dos corretivos como forma de reparos. O que Benthan faz questão de esconder é que a aplicação da dor depende também do consentimento do outro; logo, passa a ser relevante sublinhar a utopia da lei universal como redutora de dor e ampliadora de prazer.

10. Ver em especial Hulsman e de Celis (1993); Hulsman, (1990:71-89); (1989:87125) e (1997:189-213).

11. Evandro Lins e Silva (1991) afirma que o humanismo do pós-guerra fez aparecer em Gênova, em 1945, o Centro de Estudos de Defesa Social. Grammatica pensava que era necessário substituir o direito penal por um direito de defesa social, e que isto exigia um movimento social pluralista, sem filiação a qualquer escola filosófica, posicionando-se contrariamente ao tecnicismo e ao positivismo. Mais tarde, seu principal expoente, Marc Ancel, rejeitaria a abolição do direito penal. Uma tradução conseqüente e mais atual pode ser encontrada na escola da criminologia crítica, de inspiração marxista, na qual se destaca Alessandro Baratta (1986), cuja pretensão é abolir a instituição carcerária por meio de "medidas de contenção, a aplicação da prisão ultimo ratio, a segregação, só em último caso, para os perigosos" (p. 38). Do ponto de vista abolicionista, diremos que se deixa intocável a tese da prevenção geral e da segregação de classe, esquecendo-se do efeito desta mesma tese no socialismo soviético (ver em especial Pasukanis, $L a$ téorie générale du droit et le marxisme). Todavia, a criminologia crítica mostrase sensível e favorável à supressão da prisão para adolescentes, exigindo soluções diferenciadas. O impasse se presentifica ao propor penas alternativas, facilitando, por exemplo, o sentenciamento de medidas socioeducativas consagradas no ECA - Estatuto da Criança e do Adolescente, de 1990 - como liberdade assistida e semi-internação.

12. Trata-se de um conceito que emerge de saberes envolvidos com o acontecimento e com amplitude restrita. Nos termos propostos por Foucault, com os quais também concorda Deleuze, a busca por estes conceitos leva-nos à superação dos efeitos de hegemonia promovidos pelo discurso científico fundado na precisão universal totalizadora e individualista.

13. Bauman (1998:23-30), também partindo da referida distinção proposta por Claude Lévi-Strauss, em Tristes trópicos, a respeito das sociedades antropofágicas e antropoêmicas como a nossa, incorpora a análise de Christie, mostrando o recrudescimento da penalização acoplada ao controle eletrônico das vítimas da desregulação e da privatização. Destaca também a recomendação, na sociedade de controle, para a não-resistência, que ignora a contestação revolucionária e prioriza a limpeza social daqueles que desrespeitam a lei e seus respectivos alter egos: os grupos de punição sumária e os terroristas.

14. Os abolicionistas tendem a expor quatro modelos para a substituição da pena. $\mathrm{Na}$ realidade, eles se apresentam combinados e com uma certa predileção pelo modelo conciliatório inspirado no direito civil. Na perspectiva libertária, o "modelo" educativo redimensionado para além da instrução geral revela-se mais pertinente, inclusive, como mote para a crítica. Guardadas as conhecidas objeções à concepção de "modelo", devemos às sugestões de Salete M. Oliveira a incorporação da noção de "respostas-percurso", a partir de debates acerca da pertinência da Febem para jovens infratores. Trata-se de encontrar as respostas mais adequadas para situações-problema que envolvem infrator e vítima, desvencilhando-nos da universalidade da lei e propiciando a horizontalidade na tomada de decisões, o que não implica descentralização de poderes. Importa o percurso a ser seguido em direção à descoberta do talento do jovem sob uma situação-problema e a forma de indenização da vítima ou de seus entes próximos.

15. Todd May (1996:175-185) alerta para a atualidade do anarquismo no pensamento de Deleuze e Foucault, desvencilhado do humanismo ao qual se filiou o anarquismo do século XIX. Para ele, o estudo dos efeitos de repressão locais, enfatizados pelas análises anarquistas, é retomado pelo pós-estruturalismo, promovendo uma crítica política não-fundadora. A "anormalidade" deve ser exposta superando-se o saber anarquista, como expresso por Pietr Kropotkin em seu estudo sobre a prisão que se mantinha fiel à normalização, substituindo o crime pela cura.

16. A respeito de mídia e abolicionismo penal, ver Mathiesen (1998:77-95).

\section{REFERÊNCIAS BIBLIOGRÁFICAS}

BADIOU, A. Ética, um ensaio sobre a consciência do mal. Rio de Janeiro, Relume-Dumará, 1995. 
BARATTA, A. Criminologia crítica y crítica del derecho penal. México, Siglo XXI, 1986.

BAUMAN, Z. O mal-estar da pós-modernidade. Rio de Janeiro, Jorge Zahar Editor, 1998.

CAMUS, A. O homem revoltado. Rio de Janeiro, Record, 1996.

CHRISTIE, N. A indústria do controle do crime. Rio de Janeiro, Forense, 1998.

DELEUZE, G. "O atual e o virtual". In: ALLIEZ, E. Deleuze e a filosofia virtual. Rio de Janeiro, 34 Letras, 1996.

. Conversação. Rio de Janeiro, 34 Letras, 1995.

Foucault. São Paulo, Brasiliense, 1988.

DELMAS-MARTY, M. Modelos e movimentos de política criminal. Rio de Janeiro, Revan, 1992.

FOUCAULT, M. Microfísica do poder. Rio de Janeiro, Graal, 1978.

. La vida de los hombres infames. Buenos Aires-Montevideo, Editorial Altamira/Nordan Comunidad, 1993a.

. "Frente a los governos los derechos humanos". In: La vida de los hombres infames. Buenos Aires-Montevidéu, Editorial Altamira/Nordan Comunidad, 1993b.
FUKUYAMA, F. "Uma revolução silenciosa já começou”. O Estado de S. Paulo. São Paulo, 30/05/1999, Caderno 2, Cultura, p.D4-D8.

HULSMAN, L. "La criminologia critica y concepto de delito". In: SCHEERER, S. et alii. Abolicionismo penal. Buenos Aires, Ediar, 1989.

"Abolire la pena". In: VACARRO, S. et alii. Il dirito e il rovescio. Volontá - Laboratorio di richerche anarchiche. Milano, Edizione Volontá, 1990

"Temas e conceitos numa abordagem abolicionista da justiça criminal". In: PASSETTI, E. e DIAS DA SILVA, R.B. Conversações abolicionistas: uma crítica do sistema penal e da sociedade punitiva. São Paulo, PEPG - Ciências Sociais PUC-SP e IBCCrim, 1997, p.189-213.

HULSMAN, L. e DE CELIS, B. Penas perdidas. Niterói, Luam, 1993.

LINS E SILVA, E. "De Beccaria a Filippo Grammatica". In: ARAUJO JUNIOR (org.). Sistema penal para o terceiro milênio. Rio de Janeiro, Revan, 1991.

MATHIESEN, T. "A sociedade espectadora: o panóptico de Michel Foucault revisitado”. Margem. São Paulo, Faculdade de Ciências Sociais, PUC-SP, Educ, n.8, 1998.

MAY, T. "Pós-estruturalismo e anarquismo". Margem. São Paulo, Faculdade de Ciências Sociais PUC-SP/Educ, n.5, 1996, p.175-185.

MORIN, E. Terra-pátria. Lisboa, Instituto Piaget, 1993

SENNETT, R. Carne e pedra. Rio de Janeiro-São Paulo, Record, 1997. 